\title{
Pathomorphology of fetal and mature liver under the lead intoxication and after the correction: the review of experimental data
}

\author{
H. V. Dovhal ${ }^{* 1, A, B, E, F}, M$. A. Dovhal ${ }^{1, B-D}, 0$. A. Romanenko ${ }^{2, B, C}$ \\ ${ }^{1}$ State Establishment “Dnipropetrovsk Medical Academy of Health Ministry of Ukraine”, Dnipro, ${ }^{2}$ Dnipropetrovsk Institute of Traditional \\ \& NonTraditional Medicine, Dnipro, Ukraine
}

A - research concept and design; B - collection and/or assembly of data; C - data analysis and interpretation; D - writing the article; $\mathrm{E}$ - critical revision of the article; $\mathrm{F}$ - final approval of the article

\begin{abstract}
Lead is one of the most widespread pollutant which alters the mature liver and is especially harmful for the fetal liver. The typical alterations in the mature liver after the lead exposure are the hypertrophy and vacuolization of hepatocytes, circulatory disorders, mononuclear cellular infiltration. The morphological changes in the liver during prenatal development under the maternal lead treatment are inhibition of hematopoiesis, dystrophy of hepatocytes, disturbances in the liver architecture, its vessels and stroma with a gradient of pathological changes toward the peripheral parts of the organ. The manifestations of liver alteration after birth become deeper with age and develop to the necrosis, edema and inflammation. The biochemical disturbances in the liver are the decrease in the activity of enzyms of energy metabolism, inhibition of protein and nucleic acids synthesis, imbalance of the lipid peroxide oxidation system, and the increasing of oxidative stress with the further alteration of the membranes of the endothelium, red blood cells, hepatocytes, as well as mitochondrial membrane.

The changes in expression of the immunohistochemical markers can differentiate the processes in the liver, which are relatively stable or sensitive to lead, especially in prenatal development, whereas the biochemical parameters are valuable for estimation of the liver damage in postnatal life. The immunohistochemical changes under the lead treatment reflect the inhibition in protein synthesis such as albumin and cytokeratins, as well as growth factors, nitric oxide synthases and matrix metalloproteinases expression; whereas the expression of apoptotic markers increases. The search for the natural products, dietary supplements and drugs with the protective properties is ongoing and covers the wide spectrum of agents, including vitamins, micro- and macroelements, antioxidants, chelating agents, natural extracts, proteins, sorbents and complex-producing drugs. The immunohistochemical markers as well as biochemical parameters can be used to prove the efficacy of protectants for chronic lead intoxication.
\end{abstract}

\section{Патоморфологія плодової та зрілої печінки при інтоксикації свинцем і в умовах корекції: огляд експериментальних даних}

\section{Г. В. Аовгаль, М. А. Аовгаль, О. А. Романенко}

Свинець $є$ одним із найпоширеніших токсикантів, який порушує функціонування печінки у зрілому віці, особливо небезпечний для печінки у пренатальному періоді онтогенезу. Типові порушення у зрілій печінці після впливу свинцю гіпертрофія та вакуолізація гепатоцитів, порушення кровообігу, мононуклеарна клітинна інфільтрація. Морфологічні зміни в печінці під впливом сполук свинцю у пренатальному розвитку - інгібування гемопоезу, печінкова дистрофія, порушення в архітектурі печінки, ураження судин і строми з наростанням патологічних змін у напрямі до периферичних відділів органа. Ураження печінки, що викликане свинцем при пренатальному його впливі, після народження стає глибшим і характеризується некрозами, вираженими набряками і запальними змінами. Біохімічними порушеннями в печінці під дією сполук свинцю є зниження активності фрерментів енергетичного обміну, пригнічення синтезу білка, нуклеїнових кислот, дисбаланс системи перикисного окислення ліпідів і наростання ознак оксидативного стресу, що викликає пошкодження мембран ендотеліальних клітин, еритроцитів, гепатоцитів, а також мітохондріальної мембрани.

Використання імуногістохімічних маркерів дає змогу диференціювати процеси в печінці, які відносно стійкі або чутливі до свинцю, особливо у пренатальному розвитку, а біохімічні параметри необхідні для оцінювання пошкоджень печінки в постнатальному періоді. Імуногістохімічні зміни в печінці під впливом сполук свинцю відбивають інгібування синтезу білків, як-от альбумін і цитокератини, а також експресію факторів росту, синтаз оксиду азоту, матриксних металопротеїназ і посилення експресії апоптотичних маркерів. Пошуки натуральних продуктів, харчових добавок і препаратів із захисними властивостями тривають та охоплюють широкий спектр речовин, включаючи вітаміни, мікро- і макроелементи, антиоксиданти, хелатувальні агенти, натуральні екстракти, білки, сорбенти і комплексні препарати. Імуногістохімічні маркери та біохімічні показники можуть використовуватися як доказ ефективності протектантів, що застосовуються при хронічній інтоксикації свинцем.

\section{Патоморфология плодной и зрелой печени при интоксикации свинцом и в условиях коррекции: обзор экспериментальных данных}

\section{Г. В. Аовгаль, М. А. Аовгаль, А. А. Романенко}

Свинец является одним из самых распространенных токсикантов, который нарушает функционирование печени в зрелом возрасте и особенно опасен для печени в пренатальном периоде онтогенеза. Типичные нарушения в зрелой
Key words: fetal liver, mature liver, pathology, heavymetal poisoning, therapies investigational.

Pathologia 2019; 16 (1), 139-144 Dol: 10.14739/2310-1237. 2019.1.166497

*E-mail: dovgalgem@i.ua
Ключові слова: печінка, патологія, отруєння важкими металами, методи лікування.

Патологія. - 2019. T. 16, № 1(45). -

C. $139-144$ 
Ключевые слова: фетальная печень, зрелая печень, патоморфология, отравление тяжемыми метаммами, методы лечения.

Патология. - 2019. T. 16, № 1(45). C. 139-144

печени после воздействия свинца - гипертрофия и вакуолизация гепатоцитов, нарушения кровообращения, мононуклеарная клеточная инфильтрация. Морфологические изменения в печени под влиянием соединений свинца в пренатальном развитии - ингибирование гемопоэза, печеночная дистрофия, нарушения в архитектуре печени, поражение сосудов и стромы с нарастанием патологических изменений по направлению к периферическим отделам органа. Поражение печени, вызванное свинцом при пренатальном воздействии, после рождения становится более глубоким и характеризуется некрозами, выраженными отеками и воспалительными изменениями. Биохимическими нарушениями в печени под действием соединений свинца являются снижение активности фрерментов энергетического обмена, подавление синтеза белка, нуклеиновых кислот, дисбаланс системы перекисного окисления липидов и нарастание признаков оксидативного стресса, вызывающего дальнейшее повреждение мембран эндотелиальных клеток, эритроцитов, гепатоцитов, а также митохондриальной мембраны.

Использование иммуногистохимических маркеров позволяет дифференцировать процессы в печени, которые относительно устойчивы или чувствительны к свинцу, особенно в пренатальном развитии, тогда как биохимические параметры больше подходят для оценки повреждений печени в постнатальном периоде. Иммуногистохимические изменения в печени под влиянием соединений свинца отражают ингибирование синтеза белков, таких как альбумин и цитокератины, а также экспрессию факторов роста, синтаз оксида азота, матриксных металлопротеиназ и усиление экспрессии апоптотических маркеров. Поиски натуральных продуктов, пищевых добавок и препаратов с защитными свойствами продолжаются и охватывают широкий спектр веществ, включая витамины, микро- и макроэлементы, антиоксиданты, хелатирующие агенты, натуральные экстракты, белки, сорбенты и комплексные препараты. Иммуногистохимические маркеры, как и биохимические показатели могут быть использованы для доказательства эффективности протектантов, которые применяются при хронической интоксикации свинцом.

The studies of the harmful impact of the heavy metals are important nowadays by reason of rising level of environmental pollution. Lead - one of the most widespread cumulative pollutants - is known as an agent that demonstrates the toxic properties and impacts the fetal development $[4,8,14,30]$. It alters most of the metabolic systems of the cell by its ability to inhibit enzymes [8]. The liver is particularly sensitive to lead impact due to the high activity of the numerous enzymatic processes with the different manifestations in pre- and postnatal life [6]. It was found that the main toxic effect of lead in the mature liver was the alteration of membranes of the endothelium, red blood cells and hepatocytes [12]. The typical morphological changes in the liver in experiments with short period lead treatment were the hypertrophy of hepatocytes, vacuolization of cytoplasm, portal space and central vein dilatation, congested central veins, narrowing or even obliteration of sinusoids and the activation of macrophages and lymphocytes with further mononuclear cellular infiltration of the portal tracts $[11,26]$. The degree of the liver alteration was dependent on the duration of lead exposure [11]. The submicroscopic changes of hepatocytes included the alteration of mitochondria, nuclei and membranes of hepatocytes. There were signs of cytolysis, karyolysis, dissociation of hepatocytes, hyperplasia of mitochondria, swelling of their matrix, dissociation and disappearance of the mitochondrial crists. The terminal disturbance in hepatocytes differentiation was the lack of their polyploidization [11]

The biochemical disturbances in the mature liver of experimental animals under the lead treatment included the inhibition of the protein synthesis resulting in the drop of total protein concentration in the blood, the lipid and carbohydrate metabolism disorders, which led to increase of the triglycerides and glucose level in the blood, whereas the concentration of total lipids and cholesterol tended to decrease $[1,23]$. The metabolic disorders were accompanied by the morphological signs of hepatocytes alteration, the increase of the size of hepatocytes and their nuclei with the diminishing of nucleic acids concentration in the nuclei and cytoplasm [1]. The DNA became fragmentated significantly in the liver of rats exposed to lead [25]. Lead also caused the disturbance in the lipid peroxide oxidation system in the mature liver and inhibition of the aminoacids and other small molecules transformation into glucose, which impaired the normal function of mitochondria [20]. The mitochondrial membranes and cell membranes became more vulnerable $[23,25]$.

It has been recently reported that the activity of the glutathione peroxidase and superoxide dismutase was decreased in the liver of lead treated rats [31], meanwhile the concentration of malondialdehyde and tumor necrosis factor was increased [13]. The synthesis of the constitutive form of nitric oxide synthase (eNOS) was altered as well, and the synthesis of the inducible form of enzyme increases $[3,9]$. This shift in the expression of nitric oxide synthase developed along with the morphological signs of vascular disorders and alteration of stromal components [5]. The significant increase of liver enzymes such as glutamic pyruvate transaminase, alanine and aspartate aminotransferases was observed in the blood of lead treated animals [26]. The decrease in the activity of dehydrogenases, monooxygenases, superoxide dismutase, glutathione transferase, glutathione reductase, and, in turn, the decline in the concentration of glutathione is believed to be the basis of circulatory disorders in the liver under the influence of lead $[23,28,31]$. The disturbance in biochemical parameters took place under the high dosage of the lead [13], meanwhile the lead exposure of the low or moderate dosage did not cause the significant deviations in serum aspartate aminotransferase, alanine aminotransferase, alkaline phosphatase, lactate dehydrogenase activities and did not not change the serum lipid profile [22].

Lead intoxication during pregnancy caused the reduction of liver weight in newborn rats. It also led to the increase of the level of oxidative stress, meanwhile the level of hepatic mRNA, DNA, protein and antioxidant enzyme activities decreased [20]. The lead impact during pregnancy caused the liver dystrophy and decomposition of liver lobules in newborn rats and during the first month after birth, as well as the sinusoidal hypertrophy, edema of interstitial spaces, lymphocyte infiltration of the portal tracts, and the reduction of glycogen in hepatocytes 
$[3,10,25]$. There was the introlobular necrosis of the liver tissue accompanied by the periportal macrophage-lymphocytic infiltration along the interlobular veins. The venous congestion, sludge of red blood cells, damage of the wall of the interstitial veins and arteries were observed. The necrosis of the hepatic parenchyma, which became multilobular, had been exacerbated by the end of the second month. The type of necrosis was coagulatory or colliquated. The vascular disorders included the disseminated erythrocyte sludge in sinusoid capillaries, stasis and hemolysis in central veins $[10,25]$.

The deep tissue alterations like mentioned before has never been observed in the fetal liver [2,5]. The dystrophic phenomena as a change in the density of the cytoplasm of hepatocytes occurred from the $11^{\text {th }} \mathrm{em}$ bryonic day in the lead treated embryos. The inhibition of the synthesis of acid glycosaminoglycans which are essential for the normal development of the connective tissue in the embryonic liver up to end of the prenatal period was also observed $[5,7]$. The earliest sign of the suppression of acid glycosaminoglycans synthesis was their total absence between the endothelium of sinusoids and hepatocytes. The acid glycosaminoglycans provide the processes of cell migration, and thus affect the formation of tissue architecture [6]. The further tissue decomposition in the fetal liver under the lead treatment might be due to decrease in acid glycosaminoglycans concentration. These matrix components are normally present subcapsulary in the liver and in the places where the hepatic parenchyma contacts with the mesenchyma of the body. The acid glycosaminoglycans are believed to be the conductor for cell migration of mesenchyme from the trunk and septum transversum to the liver [7]. The inhibition of the migration of these cells may have consequences in the misdevelopment of the liver vessels and the general disturbance in the tissue architecture.

The reduction of glycogen content in hepatocytes of the fetal liver was observed after maternal administration of the lead $[2,25]$. Lead was also described as an agent that stimulated the proliferation of stellate cells (Ito cells) in the rat fetal liver, which can be detected by the marker of $\alpha$-smooth muscle actin ( $\alpha \mathrm{SMA})$ and were mostly located along the sinusoids [6]. The concentration of these cells had increased since the $14^{\text {th }}$ embryonic day till the end of fetal period and seemed to be maximal in the areas with the severe dystrophic alteration of the liver of lead treated fetuses [9]. The fibrotic changes in the liver of lead treated fetuses were accompanied by the accumulation of Ito cells. aSMA-positive cells were also observed in the walls of the blood vessels of the intact or altered areas [21].

Other immunohistochemical markers enable to give an additional piece of information about molecular changes in the liver of lead treated fetuses. On the $16^{\text {th }}$ embryonic day, a part of parenchymal cells in the intact liver which were positive on albumin could belong to populations of bipotential cells [6], but later the further increase in the number of hepatocytes was observed, so after the $16^{\text {th }}$ day this bipotential population produced cells of the liver parenchyma only [9]. The immunohistochemical researches showed that lead caused the inhibition of albumin synthesis in hepatocytes [9]. This protein is the main marker of maturation of the liver cells. The inhibition of albumin production indicates that lead impacts the most stable molecular processes in hepatocytes, and, perhaps, suppresses the differentiation of hepatocytes from bipotential cell population. The general degenerative phenomena in the liver parenchyma were correlated to the decrease of cytokeratins AE1/AE3 expression [21]. The lead impact on the vascular endothelial growth factor (VEGF) expression in the fetal liver resulted in the non-uniform pattern of immunostaning in the liver parenchyma, whereas the VEGF expression was intact in the stroma [21]. The increase in the number of the caspase-3-positive nuclei was observed in the liver epithelium under lead treatment. The alteration of the stroma was accompanied by the strong caspase- 3 expression in the nuclei of stromal cells and the decrease in matrix metalloproteinases MMP1 and MMP-9 expression [21]. The significant impact of the lead on the vascular endothelium was revealed in eNOS expression. Lead exposure stimulated the production of the inducible form of enzyme. After the maternal exposure before pregnancy and ongoing treatment in early prenatal development, the eNOS expression was weak in all the types of vessels and the suppression of enzyme activity was stable till the end of fetal period [9]. The suppression of the synthesis of the constitutive form of nitric oxide synthase, especially in small caliber vessels, was corresponding to the general toxic effect of lead, which was also observed in the mature liver [29].

The decrease in the specific hepatocyte volume in the rat fetal liver under the maternal lead exposure is another possible cause of the disassembly of the liver tissue [5]. The most severe consequences of lead treatment were observed for the liver hematopoietic cells. The inhibition of the proliferation of hematopoietic cells was almost total. The rapidly proliferating population of blood cells may be the most vulnerable to the impact of toxicant due to hypoxia, which is a result of vascular disorders [2,14].

The tissue pathology in the rat fetal liver showed the clear gradient pattern with the increase of the morphological changes towards the peripheral parts of organ [5]. It can also be explained by the gradient of vascular damage in the liver. The dystrophic changes had rapidly transformed into partial necrosis and fibrosis of hepatic parenchyma up to the end of the fetal period. The vascular network was well developed in the areas with the replacement of the liver parenchyma by the fibrous tissue [5]. There was not the lymphohistiocytic infiltration in the liver parenchyma of lead treated fetuses, which was a regular finding in the liver of the lead exposed rat in postnatal life [24]. The lack of the immune reply in the fetal liver is a result of immaturity of the immune system of the fetus and its inhibition by the toxicant [14].

The dystrophic changes in hepatocytes under the lead treatment during the fetal period are dependent on terms of toxicant administration. There were much more pronounced morphological alterations in the liver if the maternal lead exposure had lasted a few weeks before pregnancy [5], than with only lead treatment after fertilization or later [10]. In this case the lead accumulation does not occur in the mother's body. There is evidence that the lead administration before pregnancy can negatively 
affect the development of embryo, because the pregnancy causes a release of lead ions from the maternal organs, which are depots of lead [10]. The largest amount of lead comes through the placental barrier when the placenta starts to form. When the lead is getting into the body of pregnant females, the significant morphological changes in the placenta are being observed, which is a reason for the further damage of the internal organs of the fetus, in particular the liver and kidneys [10]. Pregnancy, as a stress factor, increases the absorption of lead. Thus, the damage of the fetal liver in the experiments with lead administration before pregnancy is precisely caused by the previous accumulation of lead in the maternal organs and its further release from the depots during the early period of pregnancy $[2,5]$.

The search for the drugs with the protective properties to lead has been carrying out along with the studies of lead toxic effects. The antioxidants, chelating agents, sorbents and complex-producing drugs were proposed for the prevention and treatment of chronic lead intoxication. It is proved that the lead negative impact increases with low concentrations of minerals, micro- and macroelements in the diet [2]. The reducing of the lead absorption from the gastrointestinal tract in the presence of other metals or minerals can be explained by the competitive interaction. In comparative studies of complex-producing protectant as casein and sorbent as charcoal it was proved that the first had more positive effect for the level of liver enzymes [23].

The antioxidants compose the group of drugs which has been investigated the most. Selenium and a-tocopherol showed the positive effect for the level of aspartate and alanine transaminases, total protein, urea, creatinine, superoxide dismutase and glutathione, as well as the lipid peroxidation index [33]. Some drugs like morpholine salt of titanic acid with membrane stabilizing and antioxidant properties and sulfur-containing products inproved hepatocytes morphology and biochemical parameters [1]. The use of a-tocopherol-containing natural products like cod liver oil for the correction of chronic lead intoxication caused the moderate membrane-protective effect in hepatocytes, the conservation of mitochondria and the maintenance of their proliferation [14]. The oxidative stress induced by lead caused the increase in reactive oxygen species, total protein carbonyl content and lipid perioxidation products in the rat liver, whereas the administration of Moringa oleifera seed powder restored all the parameters in the organ and the blood [12]. It has been proved that the caloric restriction prevented partly the harmful impact of lead and restored some parameters which depended on the liver function: the activity of glutathione peroxidase, superoxide dismutase, the concentarion of malondialdehyde and tumor necrosis factor; the biochemical findings were supported by the histological studies which pointed to the attenuation of the inflammatory processes in the liver [13].

The positive shifts in the metabolic profile of lead treated rats occurred after addition of artichoke extract and vitamin $\mathrm{C}$ to the diet. The significant decrease of the serum lead, alanine and aspartate transaminases, alkaline phosphatase and malondialdehyde and improvement of the lipoprotein profile were observed [24]. Less pronounced degeneration of the liver parenchyma and reducing of vessels congestion were observed after the administration of protectants. The diminution of lymphocyte infiltration in the liver was the morphological evidence of the protective effect. It was proved that green tea extract [31] and extract of rosemary [32] had the positive effect for the level of the liver enzymes and serum protein as well as for the liver morphology. It has been found that the natural flavonoids prevented the tissue damage caused by lead due to maintaining of the activity of eNOS and inhibition of apoptosis [29]. According to the group of researchers [28], in the liver these agents can smooth the manifestations of oxidative stress and reduce hyperlipidemia in lead treated animals. The increase of 8-hydroxydeoxyguanosine as a marker of the DNA-damage induced by lead as well the caspase- 3 activity in the rat liver was effectively suppressed by puerarin (flavonoid), so lead-induced apoptosis might be reversible [29].

The search for the natural products, dietary supplements and drugs, which can improve the state of liver in case of intoxication with heavy metals, is ongoing. Extract of tomatoes (Lycopersicon esculentum) [15, 21], and garlic (Allium sativum) [17], have significant hepatoprotective effect, but it was not the same for different metals. The highest hepatoprotective effect of extract of tomatoes was to cadmium and mercury and it showed the least protective property for lead [15]. The same tendency was revealed for the garlic extract and Garcinia kola extract $[17,18]$. The most toxic effect of lead for the liver among other heavy metal was also proved when the Ground Zingiber officinale or palm oil were used as the protectants and they were the least beneficial for lead compared to cadmium and mercury $[16,19]$.

The supplementation of natural products like spirulina or dandelion during pregnancy diminished the signs of oxidative stress, restored the level of hepatic DNA, mRNA and protein, and eliminated the inhibition of the antioxidant enzymes in the liver induced by lead [20, 34]. The powder of wine yeast Sassharamyces vini administreted before and during pregnancy showed the significant protective effect for the restoring of the blood cell population in the fetal liver; this result can be explained by its antioxidant effect. This protectant could also inhibit the absorption of lead and thus reduced the level of a toxicant in the maternal blood [5]. The microelements contained in powder of wine yeast Sassharamyces vini may also have a partial shielding effect, as it was shown in studies with the addition of calcium pectates in the diet; the concentration of lead in the blood of experimental animals was reduced [27]. Coenzyme Q10, which is capable to increase the cellular energy resources, exhibits antioxidant effects and supports cellular enzymatic systems; it had a protective effect for rat fetuses survival and liver parameters of lead treated fetuses $[4,5]$. The morphological and immunohistochemical findings proved that the coenzyme Q10 was less protective compared to wine yeast Sassharamyces vini, perhaps, because it did not affect the absorption of lead from the gastrointestinal tract [9]. Lycopene (pigment of tomato) as a protectant for lead treated fetuses restored partly the AE1/AE3 expression in the liver, and also caused the decrease in caspase- 3 expression, but did not change VEGF, MMP-1 
and MMP-9 expression. The positive effect was observed for the quantity and distribution of aSMA-positive cells [21]. All the manifestations of morphological pathology were smoothed with the correction of wine yeast Sassharamyces vini, but not of coenzyme Q10. Both of protectors can partially mask the influence of lead and reduce the suppression of the activity of eNOS [9]. Some vessels of medium caliber saved the sufficient level of eNOS activity regardless of the degree of impairment of hepatic parenchyma, whereas specific hepatocyte volume did not change significantly after the addition of protectants [9].

\section{Conclusions}

1. The morphological changes in the liver under the lead exposure are different in prenatal and postnatal period. The main pathological features in the fetal liver are inhibition of hematopoiesis, dystrophy of hepatocytes, disturbances in the liver architecture, vessels and stroma, all the alterations become deeper after birth. The typical morphological changes in the mature liver after the lead exposure are the hypertrophy and vacuolization of hepatocytes, circulatory disorders, signs of inflammation; their expression is dependent on terms of toxicant administration.

2. The changes in expression of the immunohistochemical markers can differentiate the processes in the liver, which are relatively stable or sensitive to the lead, especially in prenatal development. The most vulnerable processes are the synthesis of the proteins, expression of markers of apoptosis, growth factors and enzymes.

3. The search for the natural products, dietary supplements and drugs with the protective properties is ongoing and covers the wide spectrum of agents. The immunohistochemical markers as well as morphological, histochemical or biochemical parameters can be used as testimonies to prove the efficacy of protectants.

Prospects for further research. The further development in this direction involves the search of new drugs with more protective effect, and broadening the range of the morphological, histochemical, biochemical and immunohistochemical methods to confirm the effectiveness of the agents with protective properties.

Conflicts of interest: authors have no conflict of interest to declare. Конфлікт інтересів: віАсутній.

Надійшла Ао редакції / Received: 02.10.2018

Після Аоопрацювання / Revised: 15.10.2018

Прийнято Ао Аруку / Accepted: 01.11.2018

\section{Information about authors:}

Dovhal H. V., MD, PhD, DSc, Professor, Head of the Department of Human Anatomy, State Establishment "Dnipropetrovsk Medical Academy of Health Ministry of Ukraine", Dnipro.

Dovhal M. A., MD, PhD, DSc, Professor, Head of the Department of Pathological Physiology, State Establishment "Dnipropetrovsk Medical Academy of Health Ministry of Ukraine", Dnipro, Ukraine. Romanenko 0. A., MD, PhD, Associate Professor of the Deparment of Surgery, Dnipropetrovsk Institute of Traditional \& NonTraditional Medicine, Dnipro, Ukraine.
Відомості про авторів:

Аовгаль Г. В., А-р меА. наук, професор, зав. каф. анатомії мюАини, АУ "Аніпропетровська медична академія М03 України", м. Аніпро.

Аовгаль М. А., А-р меА. наук, професор, зав. каф. патологічної фізіології, АУ "Аніпропетровська медична академія М03 України", м. Аніпро.

Романенко А. А., канА. меА. наук, Аоцент каф. хірургії, Аніпропетровський меАичний інститут траАиційної і нетрадиційної медицини, м. Аніпро, Україна.

\section{Сведения об авторах:}

Аовгаль Г. В., А-р мед наук, профессор, зав. каф. анатомии человека, ГУ "Анепропетровская меАицинская академия МЗ Украины", г. Анепр.

Аовгаль М. А., А-р меА наук, профессор, зав. каф. патологической физиологии, ГУ “Анепропетровская медицинская академия МЗ Украины", г. Анепр.

Романенко А. А., канА. меА. наук, Аоцент каф. хирургии, Анепропетровский медицинский институт традиционной и нетрадиционной медицины, г. Анепр, Украина.

\section{References}

[1] Aleksijchuk, V. D., Sokurenko, L. M., \& Omelchuk, S. T. (2015) Osoblyvosti vplyvu nanochastok sulfidu ta nitratu svyntsiu na orhanizm eksperymentalnykh tvaryn u rizni periody doslidzhennia ta metody korektsii yikh nehatyvnoi dii [Peculiarities of lead sulphide and nitrate nanoparticles influence on organisms of experimental animals in different research periods and methods of its negative impact correction]. Svit medytsyny ta biolohii, 54(4), 97-100. [in Ukrainian].

[2] Belska, lu. O (2016) Osoblyvosti morfolohii fetalnoi pechinky pid vplyvom atsetatu svyntsiu ta za umov korektsii mikroelementamy [Morphological features of fetal liver under the influence of lead acetate and in case of correction by microelements]. Visnyk problem biolohii $\mathrm{i}$ medytsyny, 128(2), 327-330. [in Ukrainian].

[3] Vylegzhanina, T. A. (2015) Vliyanie acetata svinca na razvitie pechen krys [The influence of lead acetate on development of liver of rats]. Medicinskij zhurnal, 2(52), 44-48. [in Russian].

[4] Dovgal, G. V. (2014) Vplyv atsetatu svyntsiu na vyzhyvanist zarodkiv shchuriv ta mozhlyvist korektsii [Influence of Lead Acetate on Rat Embryons Survival and under the Correction]. Visnyk problem biolohii i medytsyny, 105(1), 93-96. [in Ukrainian].

[5] Dovgal, G. V. (2014) Morfolohichni zminy v rozvytku pechinky shchuriv pry vplyvi atsetatu svyntsiu ta za umov korektsii v prenatalnomu periodi [Morphological changes in the development of rat liver after the lead acetate treatment and under the correction in the prenatal period] Ukrainskyi morfolohichnyi almanakh, 12(1), 42-44. [in Ukrainian]

[6] Dovgal, G. V. (2013) Morfolohichni zminy v rozvytku pechinky shchuriv pry vplyvi atsetatu svyntsiu ta za umov korektsii v prenatalnomu periodi [Morphological and molecular biological characteristics of prenatal development of rat liver].Ukrainskyi morfolohichnyi almanakh, 11(4), 22-26. [in Ukrainian].

[7] Dovgal, G. V. (2014) Rol kyslykh hlikozaminohlikaniv v prenatalnomu rozvytku pechinky shchuriv [The role of acid glycosaminoglycans in the prenatal development of the rat liver]. Visnyk problem biolohii $i$ medytsyny, 109(2), 257-259. [in Ukrainian]

[8] Koshkina, V. S., Kotlyar, N. N., Kotelnikova, L. V., \& Dolgushina, N. A. (2013) Kliniko-toksikologicheskaya kharakteristika svinca i ego soedinenij [Clinical and toxicological properties of lead and its compounds] Medicinskie novosti, 1, 23-26. [in Russian]

[9] Romanenko, A. A., Dovgal, G. V., \& Dovgal, M. A. Imunohistokhimichne doslidzhennia pechinky shchuriv v piznomu prenatalnomu periodi pid vplyvom atsetatu svyntsiu ta za umov korektsii [The Immunohistochemical Examination Of RatLiver In The Late Embryonic Period Under The Influence Of Lead Acetate And After Correction].Visnyk problem biolohii i medytsyny, 102(3), 158-161. [in Ukrainian]

[10] Shubina, O. S., \& Kireeva, Yu. V. (2008) Vliyanie svincovoj intoksikacii na morfofunkcional'noe sostoyanie sistemy placenta-plod [Influence of Lead Intoxication on Morphofunctional Condition of System of Patient-Fetus]. Vestnik Orenburgskogo gosudarstvennogo universiteta,6(88), 118-121. [in Russian].

[11] Metwally, E. S.A.M., Negm, F. A., El-din, R. A.S., \& Nabil, E. M. (2015) Anatomical and histological study of the effect of lead on hepatocytes of albino rats. International Journal of Biomedical Materials Research, 3(4), 34-45. doi: 10.11648/j.ijbmr.20150304.11

[12] Velaga, M. K., Daughtry, L. K., Jones, A. C., Yallapragada, P. R., Rajanna, S., \&Rajanna, B. (2014) Attenuation of lead-induced oxidative stress in rat brain, liver, kidney and blood of male Wistar ratsby Moringa oleifera seed powder. J Environ Pathol Toxicol Oncol, 33(4), 323-37. 
[13] Mohammadi, M., Ghaznavi, R., Keyhanmanesh, R., Sadeghipour, H. R., Naderi, R., \&Mohammadi, H. (2014) Caloric restriction prevents lead-induced oxidative stress and inflammation in rat liver.Scientific World Journal,5. doi: 10.1155/2014/821524.

[14] Hassan, R. A., Amin, D. M.,Rahmy, N. A.,Hatem, M. E., \& Dessouky, M. I. (2012) Clinicopathological, histopathological and immunological studies on animals exposed to lead and cadmium under experimental conditions. N Y Sci J, 5(12), 120-136.

[15] Nwokocha, C. R., Nwokocha, M. I., Aneto, I., Obi J., Udekweleze, D. C. Olatunde B., et al.(2012) Comparative analysis on the effect of Lycopersicon esculentum (tomato) in reducing cadmium, mercury and leadaccumulation in liver. Food Chem Toxicol, 50(6), 2070-3. doi: 10.1016/j.fct.2012.03.079

[16] Nwokocha, C. R., Nwokocha, M. I., Owu, D. U., Obi, J., Olatunde, B. Ebe, C., et al.(2012) Comparative analysis on the effect of palm oil (Elaeis guineensis) in reducing cadmium and lead accumulation in liver of Wistar rats. Pharmacognosy Res,4(4), 214-8. doi: 10.4103/09748490.102266

[17] Nwokocha, C. R., Owu, D. U., Nwokocha, M. I., Ufearo, C. S., \& Iwuala, M. O.(2012) Comparative study on the efficacy of Allium sativum (garlic) in reducing some heavy metal accumulation in liver of wistar rats. Food Chem Toxicol, 50(2), 222-6. doi: 10.1016/j.fct.2011.11.003

[18] Nwokocha, C. R., Owu, D. U., Ufearo, C. S., \& Iwuala, M. O.(2011) Comparative study on the efficacy of Garcinia kola in reducing some heavy metal accumulation in liver of Wistar rats. J Ethnopharmacol, 135(2), 488-91. doi: 10.1016/j.jep.2011.03.049

[19] Nwokocha, C. R.,Owu, D. U., Nwokocha, M. I., Ufearo, C. S., \& Iwuala, M. O. (2012) Comparative study on the hepatoprotection to heavy metals of Zingiber officinale. Pharmacognosy Res, 4(4), 208-13. doi: 10.4103/0974-8490.102263

[20] Gargouri, M., Magné, C., Ben Amara, I., Ben Saad, H., \& El Feki, A. (2017) Dandelion-enriched diet of mothers alleviates lead-induced damages in liver of newborn rats. Cell Mol Biol., 63(2), 67-75. doi: $10.14715 / \mathrm{cmb} / 2017.63 .2 .10$

[21] Dovhal, H. V., Dovhal, M. A., \& Romanenko, O. A. (2017) The expression of immunohistochemical markers in the fetal liver after maternal exposure of lead acetate and under the correction. Science Rewiew, 7, 17-19.

[22] Allouche, L., Hamadouche, M., Touabti, A., \& Khennouf, S. (2011) Effect of long term exposure to low or moderate lead concentrations on growth lipid profile and liver function in albino rats. Advan Biol Res, $5(6), 339-47$.

[23] Hanan, A. A., \& Riham, M. R. (2012) Effect of lead toxicity on cytogenisity, biochemical constituents and tissue residue with protective role of activated charcoal and casein in male rats. Environ. Australian Journal of Basic and Applied Sciences, 6(7), 497-509.

[24] Heidarian, E., \& Rafieian-Kopaei, M. (2013) Protective effect of artichoke (Cynara scolymus) leaf extract against lead toxicity in rat. Pharm Biol, 51(9), 1104-9. doi: 10.3109/13880209.2013.777931

[25] Hegazy, A., \& Fouad, U. (2014) Evaluation of lead hepatotoxicity; histological, histochemical and ultrastructural study. Forensic Medicine and Anatomy Research, 2, 70-79. doi: 10.4236/fmar.2014.23013

[26] Haouas, Z., Sallem, A., Zidi, I., Hichri, H., Mzali, I., \& Mehdi, M. (2014) Hepatotoxic effects of lead acetate in rats: histopathological and cytotoxic studies. J Cytol Histol, 5, 256. doi: 10.4172/2157-7099. 1000256

[27] Khotimchenko, M., Makarova, K., Khozhaenko, E., \& Kovalev, V. (2017) Lead-binding capacity of calcium pectates with different molecular weight. Int J Biol Macromol, 97, 526-535. doi: 10.1016/j.ijbiomac.2017.01.065

[28] Liu, C. M., Ma, J. Q., \& Sun, Y. Z. (2011) Protective role of puerarin on lead induced alterations of the hepatic glutathione antioxidant system and hyperlipidemia in rats. Food Chem Toxicol, 49, 3119-27. doi: 10.1016/j.fct.2011.09.007

[29] Liu, C. M., Ma, J. Q., \& Sun, Y. Z. (2012) Puerarin protects the rat liver against oxidative stress-mediated DNA damage and apoptosis induced by lead. Exp Toxicol Pathol., 64(6), 575-82. doi: 10.1016/j. etp.2010.11.016

[30] Zhu, M., Fitzgerald, E. F., Gelberg, K. H., Lin, S., \& Druschel, C. M. (2010) Maternal low-level lead exposure and fetal growth. Environ Health Perspect, 118(10), 1471-1475. doi: 10.1289/ehp.0901561

[31] Mehana, E. E., Meki, A. M. A., \& Fazili, K. M. (2012)Ameliorated effects of green tea extract on lead induced liver toxicity in rats. Exp Toxicol Pathol, 64(4), 291-5. doi: 10.1016/j.etp.2010.09.001

[32] Mohamed, W. A., Abd-Elhakim, Y. M., \& Farouk, S. M. (2016) Protective effects of ethanolic extract of rosemary against lead-induced hepato-renal damage in rabbits. Exp Toxicol Pathol, 68(8), 451-61. doi: 10.1016/j.etp.2016.07.003

[33] Elgaml, S. A., Khalil, R., Hashish, A., \& El-Murr, A. (2015) Protective effects of selenium and alpha-tocopherol against lead-induced hepatic and renal toxicity in Oreochromis Niloticus. J Aquac Res Development 6(1), 299. doi: 10.4172/2155-9546.1000299
[34] Gargouri, M., Ben Saad, H., Ben Amara, I., Magné, C., \& E Feki, A. (2016) Spirulina exhibits hepatoprotective effects against lead induced oxidative injury in newborn rats. Cell Mol Biol, 62(10), 85-93. doi: $10.14715 / \mathrm{cmb} / 2016.62 .10 .14$ 